\title{
Caste and Islamic Revivalist Movements: A Case Study of Eastern Muslims in Sri Lanka
}

\author{
ABOOBACKER RAMEEZ ${ }^{1}$
}

\begin{abstract}
Caste exists in all South Asian societies. Although the caste has become contentious among Sinhalese and Tamils in Sri Lanka, it suffered a fatal blow among the Tamils during the civil war. However, it has re-emerged once again during the post-war context. In contrast, the caste among Muslims in Sri Lanka gained no significance, since Islam has not subscribed to discrimination and inequality in the form of caste. Nevertheless, one may come across endogamous groups analogous to caste and such groups are subjected to certain discrimination among Muslims. As such, this study explores whether caste still exists among the Eastern Muslims of Sri Lanka and examines the role of Islamic revivalist movements in the caste dynamics. This study employed qualitative method for data collection such as observation, in-depth interviews and focus group discussions. It was found that various groups occupying a higher or lower strata of Muslim society in the Eastern Sri Lanka existed in the past, thanks to the influence of non-Muslim neighboring communities such as Tamils, as they live side by side in the Eastern Sri Lanka. However, such caste divisions do not exist anymore, given the Islamic revivalism that swept through South Asia including Sri Lanka in 1970s. Moreover, the study has also found that the advancement of education, westernization and globalization contributed significantly to erosion of caste discrimination among the Muslims in Eastern Sri Lanka.
\end{abstract}

Keywords: caste discrimination, education, globalization, Islamism, Islam in Sri Lanka

Caste system, which has been in existence in South Asia over the past three millennia and is an integral part of Hindu ethos, social structure and cultural traditions, is a unique hierarchical system of social stratification. Among the different social stratifications exist in the society, caste can be named as one of them. The term caste was derived from Spanish word 'casta' meaning breed or race (Farook 2012). Caste system is basically a way of dividing people into different social classes ranking them in a range between the highest and the lowest (Rao 2010). To be precise, it is based on the varna system comprising of four-fold division of society as well as smaller, innumerable units within the hierarchy, which are called jatis in Tamil. The overarching system of social hierarchy as represented by the varna model suggests an idealized and oversimplified picture of society. The varna model is fraught with ambiguities. The various Brahman jatis, for example, are not only endogamous but are also ranked in terms of high and low. Various jati clusters, which are generally perceived as homogenous are in fact internally differentiated and have a ranking hierarchy of their own (Dube 2010).

1 Aboobacker Rameez, Ph.D., Senior Lecturer in Sociology and Head of Department, Department of Sociology, South Eastern University of Sri Lanka, University Park, OLUVIL \#32260, Sri Lanka, email: arameez@seu.ac.lk, aramees2001@gmail.com.

https://doi.org/10.24035/ijit.13.2018.001 
There is a well-defined link between caste and occupation, as the latter is considered hereditary and is ranked in a hierarchical order. There are multiple and often contradictory hierarchies giving supremacy to different groups (e.g. Brahmans, Ksastriyas or Merchants) in different caste formations in contemporary India and, therefore, assertion of separate identities by diverse caste groups remain the more significant axis of caste when digging deep into caste politics in today's world (Guha 2013).

As the caste system is inherently inegalitarian thanks to it privileges the higher caste and excludes and discriminates the lower caste, it is suffused with injustice and gross violation of human rights. Discrimination, exclusion and humiliation experienced by the lower castes have been deeply entrenched across the South Asia and are particular reflected in access to public amenities, education, employment, entry into temples and restrictions on marriage. For instance, children from untouchable caste have to sit apart from those of the higher castes in school (Thorat \& Umarkant 2004; Jaffrelot 2006)

The influence of caste has considerably declined in recent decades under the impact of migrations, accelerating urbanization, industrialization, new economic opportunities which provide avenues of upward social mobility, modern education, legislative measure and affirmative action (Fuller 1997). However, certain features of caste system such as endogamy continue to show a remarkable resilience even in the face of massive changes in society today.

Moreover, as it exists in all South Asian societies including the Sinhala Buddhists and Tamils. Caste is intrinsically linked with Hinduism and without the latter there can be no caste. Therefore, caste must not be viewed as a problem related to a particular community, but it should be regarded as a human catastrophe that needs to be addressed both socially and legally.

Caste system was introduced to Sri Lanka from India many years ago. In Sri Lanka, both Sinhalese and Tamils have been trapped with the bane of caste shaping all spheres of their public life. Caste identity among the Jaffna society (Hindu society) is closely linked to inequality and discrimination bound by religious principles (Tudor Silva et al. 2009). However, it is argued caste has suffered a fatal blow during the civil war, which lasted for almost three (3) decades causing enormous damage on both human lives as well as properties in Sri Lanka. It is reported that the Tamil militant movement, popularly known as Liberation Tigers of Tamil Ealam (LTTE), has dealt with it with their iron hands and envisioned to create social change eliminating caste discrimination in the society. Some people argue that the only positive achievement of the LTTE was the elimination of caste discrimination through their iron hands. However, it needs to be emphasized that while caste issue is not dead fully, it is breathing its last. Therefore, it is safe to assume that caste system exists subliminally in the public sphere and is in its death throes as a despicable phenomenon.

As far as Muslims around the globe are concerned, Islam is a religion of egalitarianism and peace; there is no racial discrimination or inequality in Islam. This is an explicitly contrasting feature between Islam and other religions or other societies. Thus, caste based discrimination within the Muslim community is not evident. In the same vein, the Muslims of Sri Lanka abide by the same principles as their basic tenets and socialized their generations in line with those principles. However, it should be emphasized that one may come across distinct or endogamous groups analogous to caste groups within the Muslim society. This is aptly noted by Asiff Hussein in his detailed account on Ethnological Study of the Muslims of Sri Lanka (Hussein 2007) Moreover, it could be noticeable that a group of people in the Muslim society in Sri Lanka were excluded based on their family background and occupation, whereas another group of people were regarded superior in terms of their birth and family status. Mcgilvray's account on Caste Ideology and Interaction mildly sheds lights on the caste divisions prevalent among the Muslims in Batticalo and 
Ampara district ( Mcgilvray, 1982). Clearly speaking, some people were treated unfairly or placed in unprivileged positions, while others were treated fairly or placed in a privileged positions. As such, it is, therefore, significant to explore whether or not such caste discriminations, on the basis of birth and occupation, are still existent in the Muslim society, despite Islam professes egalitarianism as its basic tenets. Thus, this study explores whether caste still exists among the Eastern Muslims of Sri Lanka and examines the role of Islamic revivalist movements in the caste dynamics among the Muslims.

Although both Asiff and Mcgilvray dealt lightly on the classification of caste among the Muslims in Batticalo and Ampara, their studies have not entirely focused on the aspects of caste in the Muslim community in the face of Islamic movements functioning in Sri Lanka following the liberalization policy introduced in 1970s. More importantly, this study deals with how the Islamic movements have shaped the Muslims of Sri Lanka in terms of their caste practices. Unlike the previous studies that were based on theoretical aspects, this study largely discusses the findings drawn from empirical data and therefore, is significant.

\section{Methodology}

The study was carried out based on qualitative research method. The qualitative data were gathered by using primary and secondary sources.

\section{Data Collection and Sampling}

The first part of the data collection was the secondary data collected through published books, research reports, journals and online archives. The second part of data collection comprised of indepth interviews and focus group discussions under the qualitative method. 15 In-depth interviews were conducted randomly with different categories of people representing the Muslim community in the Eastern province. The people selected for the interview were: family members of Usta (deemed as lower castes), members of Moulana families, social activists, government servants, civil society representatives (religious leaders), NGO workers and other private sector employees

Furthermore, 2 focus group discussions were also conducted in 2 districts namely, Ampara, and Batticaloa with the participation of people from all walks of life. This is to ensure fair representation of all people in the FGDs is made to explore the crux of the issue and their voices to be heard. Each focus group discussion consisted of between 15 to 20 people. Qualitative data were analyzed using descriptive method with the support of tabulation and graph, and so on.

\section{Research Area}

The area of this survey is the eastern province of Sri Lanka which consists of three main districts, namely Trincomalee, Batticaloa and Ampara. The province is located in the east coast of Sri Lanka and it is bounded in the east by the Bay of Bengal, North by the Northern Province, West by the North Central and Central Provinces and South by the Uva and Southern Provinces.

The province has a total area of 9,792 sq. km. including $390 \mathrm{sq} . \mathrm{km}$. of inland waters and it occupies $16 \%$ of the total land area of Sri Lanka. The long coast line with its famous sandy beaches, large number of inland waters, mix of forest and agricultural lands and the magnificent natural harbor in Trincomalee make the Eastern Province one of the most beautiful sought after Provinces in Sri Lanka. Trincomalee is accepted as the capital of the Eastern Province (Provincial Planning Secretariat 2015). The eastern Sri Lanka is a composite mix of three major communities such as 
Muslims, Tamils and Sinhalese inhibiting the three main districts of Trincomalee, Batticaloa and Ampara. The Muslims are a majority in Trincomalee which also has a significant numbers of Sinhalese closely followed by the Tamils. In Batticaloa, the Tamils and Muslims are dominant. Ampara is Muslim majority district having a sizeable number of the Sinhalese and the Tamils.

The Map of Eastern Province

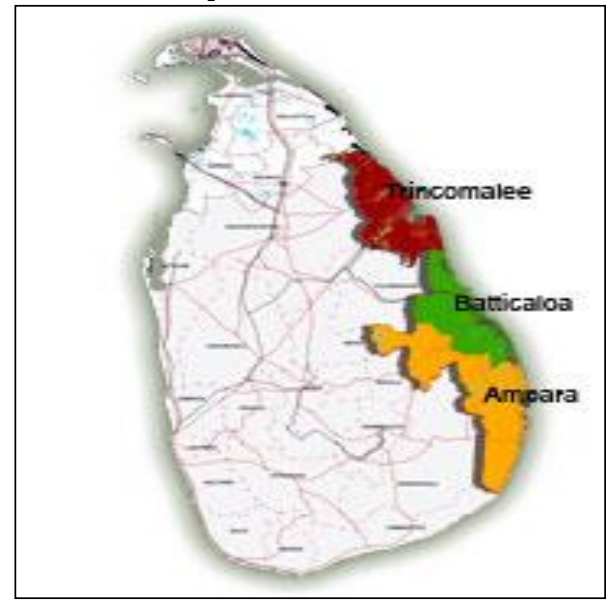

(Source: http://www.ep.gov.lk/)

Overall, Tamils followed by the Muslims and the Sinhalese dominate the Eastern province. Muslims and Sinhalese occupy the second and third position respectively. The population of Eastern Province in terms of ethnicity is given below in the table 2.2.1.

Table 1: Population of Eastern Province Based On Ethnicity

\begin{tabular}{|l|c|r|r|r|r|r|r|}
\hline Districts & \multicolumn{1}{|l|}{$\begin{array}{l}\text { GN } \\
\text { Divisions }\end{array}$} & \multicolumn{1}{l|}{$\begin{array}{l}\text { Total Land } \\
\left(\mathbf{k m}^{2} \mathbf{~}\right.\end{array}$} & Tamils & Muslims & Sinhalese & Others & Total \\
\hline Ampara & 20 & 4,415 & 112,915 & 282,484 & 251,018 & 1640 & $\mathbf{6 4 8 , 0 5 7}$ \\
\hline Batticalao & 14 & 2,854 & 424,199 & 154,197 & 3,303 & 4,902 & $\mathbf{5 8 6 , 6 0 1}$ \\
\hline Trincomalee & 11 & 2,727 & 144,613 & 184,529 & 110,679 & 1,051 & $\mathbf{4 4 0 , 8 7 2}$ \\
\hline Total & $\mathbf{4 5}$ & $\mathbf{9 , 9 9 6}$ & $\mathbf{6 8 1 , 7 2 7}$ & $\mathbf{6 2 1 , 2 1 0}$ & $\mathbf{3 6 5 , 0 0 0}$ & $\mathbf{7 5 9 3}$ & $\mathbf{1 , 6 7 5 , 5 3 0}$ \\
\hline
\end{tabular}

(Source: District Secretariats: Ampara 2012; Batticaloa 2014; Trincomalee 2011)

As Muslims in the Eastern Province account for $1 / 3$ of the total Muslim population in Sri Lanka, they are interspersed with Tamils sharing their linguistic and cultural repertoire with each other. As both communities have been living side by side for centuries, they have been able to share their linguistic and cultural stock with each other. It is not surprising that many cultural practices of Tamils including the caste aspects have permeated among the Muslims in the Eastern Province, and vice versa. Thus, this study is considered significant to explore whether there is a cultural interplay in the existence of caste discrimination among the Muslim society.

\section{Results and Discussions}

This section outlines the results and discussions of the study on caste and Islamic revivalist movements in the Eastern province of Sri Lanka and discusses the classifications of caste existent 
among the Muslims in the Eastern province. It also deals with the role the Islamic revivalist movements in the evaporation of caste divisions in the province.

Islam and Caste

The unity, equality, and brotherhood of mankind are the cardinal principles of Islamic faith. It never entertains inegalitarianism, but it reiterates on the fraternity of humanity. The Quran says that all human have been created from a single primordial pair, Adam and Eve, and are therefore equal (49:13). Islam considers the distinctions of birth, lineage, class, wealth or caste inconsequential. The only worthwhile distinction or honor is piety and moral virtue. Thus, the Quran (49:13) states:

0 , mankind! We created you from a single (pair) of a male and a female, and made you into nations and tribes, so that you may know each other. Verily the most honored amongst you in the sight of God is the one who is the most righteous of you.

The Prophet Muhammad's last sermon delivered in $10 \mathrm{AH}$ also made it explicitly clear that all the believers were equal:

O people, know that your Lord is one and your father (Adam) was one. There is no superiority of an Arab over a non-Arab, and no superiority of a non-Arab over an Arab; Nor of a red (i.e. a fair person) over a black or black over a red, except in respect of piety and righteousness (Musnad Ahamed).

Although Islam takes cognizance of social differentiation and the existence of groups that are based on descent, kinship ties and tribal affiliations, it emphasizes that such distinctions are meant to serve the purpose of social identification and that they must not be used as a criterion of ranking or hierarchy. Thus, it is clear that Islam does not recognize any distinctions based on birth, descent or caste.

Nevertheless, the study finds that a system of social stratification with different groups occupying a higher or lower strata of Muslims exists in the Eastern Sri Lanka; a group of people are marginalized, while other group of people are respected or placed in an advantageous position, despite there are no formal caste system or hierarchy among the Muslims in Sri Lanka, particularly in the Eastern Province. This could be attributed to the influence of non-Muslim neighboring communities like Tamils/Hindus in the Eastern Province. The customs such as kudi system (clan lineage), dowry and so on existent amongst the Hindus in the Eastern Province have made inroads into the Muslims' culture in the East (Hussein 2007). For instance, kudi system, which is matrilineal, numbering over 18 has an origin of Mukkuvar Tamils of Batticaloa South (Hussein 2007). This is true because that those Arabs or Moors who settled in the Eastern province married local Mukkuvar women and got the kudi system from them. This is reflected in the following response:

"As Muslims and Tamils live closer here, we share not only language, but our cultural practices like kudis, dowries too" (Interview 4)

However, the contrasting feature between kudi and caste system is that former is exogamous, while the latter is endogamous. Although the caste is seemingly not evident among the Muslims in the Eastern province, there has been an instance where people of different background have been treated well, while some other people, minute in numbers, from different background have been treated unfairly. Such discrimination poses the question whether the caste is still 
existent among the Muslims or not. As such, the following section deals with those Muslims holding high or low respect/ status in the social hierarchy in terms of caste divisions in the Eastern Sri Lanka.

\section{Moulana Families}

These people are believed to be the descendants of Prophet Muhammed through his daughter Fathima or of his close companions like Abu Bakr and are considered high on the social hierarchy. They are a small semi-endogamous set of persons claiming patrilineal descent from the Prophet's family (Mcgilvray 1982). They are apparently placed in an advantaged position in the social hierarchy of Muslim community. I visited some of the Moulana families living in Maruthamunai and Mavadippalli areas in the Ampara district. The interesting point needs to be emphasized here is that that unlike the rest of the Muslims in the East who traditionally follow the matrilineal kudi system, Moulanas are patrilineal (descent), tracing their ancestry in the direct male line to the daughter of Prophet or to his companions such as Abu Bakr. Interestingly, Moulanas adopt endogamy among themselves. Asiff Hussein (2007) quoted the work of De Munck (1993) which was based on a response from a Moulana from Dikwella:

"Being a Moulanaar is like a caste... We are from the blood of the Prophet ... My daughters passed through the patrilineal system. However, even sons should marry the daughters of Moulana families".

They engage in different types of livelihood including business for their survival. A respondent noted:

"We used to marry within our Moulana families and involve in many works including the government jobs. People respect us a lot and we treat the people nicely too" (Interview 08).

The above reference suggests that marriage system within the Moulana families is endogamous and they engage in various livelihood activities. It needs to be contrasted that the respect the Moulanas hold is not universal. In other words, the respect that Moulanas hold as higher group of people in the social strata is not prevalent in all the areas and therefore, they are no more respected in any part of the Sri Lanka, except the Eastern and Southern Sri Lanka. This is reflected in the view of a Moulana family member, as given below:

"People respected us and gave us most prominent positions in the society in the past, but that era is over now. With the arrival of Islamic movements, we have lost our pride and respect" (Interview 05).

The above assertion is self-explanatory why Moulaanas are losing their grip in the society at present. Moulanas views that their respect in the higher strata of the society has diminished with the arrival of Islamic movements in Sri Lanka. Contrastingly, the lower category in the social hierarchy of the Muslim society in the Eastern Province is Osta, who can somehow be equivalent to Sutras/untouchables in India. The following section deals with them.

Osta

https://doi.org/10.24035/ijit.13.2018.001 
The term osta itself derives from the Arabic terminology of ustad which means teacher or master. This is also an endogamous group who engage in circumcision, hair-cutting (barbers), and ritual tonsure of infants as their livelihood and they are considered lower in terms of social category/hierarchy. They are a tiny, markedly inferior, and strictly endogamous group of Muslim Barber-Circumcisers ( Mcgilvray, 1982). Generally speaking, some Muslims do not like to have dine with them, let alone inter marrying with them (Hussein 2007). Although they are dispersed in different parts of the country, they live predominantly in most of the Muslim major towns including the Eastern Province.

"Our neighbors and other people looked at us differently and treated us unfairly in the past, but that is not to be seen nowadays. We involved in lower category of jobs like circumcision, hair cutting and so on. But, nowadays we have been able to do many jobs in the society. Everybody is good with us. Those days, we could not find partners to our daughters and sons, even though they do good jobs. Now, thank God, the situation has drastically changed" (Interview 06).

It can be observed that the members of Osta were subjected to unfair treatment, that is, discrimination in the past in the domain of livelihood, marriage and so on. However, such a trend has now changed since discrimination towards Osta families ceased and they are treated fairly, just like others, in the Muslim society of Eastern province. More importantly, their livelihood patterns have significantly improved now, despite being confined to certain category of livelihood in the past. This is a significant improvement as far as the Osta families are concerned. Moreover, the researcher himself observed that Osta families have married off their daughters to people doing many jobs including Engineers and government servants in the Sainthamaruthu and Akkaraipattu area in the Ampara district. It is a positive trend in the society where discrimination existed earlier on the basis of birth and occupation directly or indirectly upon certain family members has now ceased these days. Since their professions descend from parents to offspring, it is too difficult to trace their lineage to a particular person or persons, as is the case of Moulanaas who preserves their lineages.

\section{Butchers}

This is also another group of people who is regarded low/inferior in terms of status. In fact, they are socially marginalized, may be because of their lowly occupation in the society (Hussein 2007). The mainstream Muslims have less antipathy towards this group of people compared to that of the Osta. They do not even engage in any other menial jobs except butchery and meat selling. When one of the respondents from the butchers' family avers:

"Although people treated us differently earlier, now we have no problem in dealing with all the people. No body treats us differently now, neither do we treat others unfairly" (Interview 12) .

This shows that there is no manifest difference or unfair treatment of butchers in the Muslim society at present. Furthermore, a small group of Sufi mystics (Pava, 'Bawa'; 'Fakir') whose recruitment is based upon a mixture of patrilineal descent and discipleship (Mcgilvray 1982). This group is not regarded either advantageous or disadvantageous positions in the society. However,

https://doi.org/10.24035/ijit.13.2018.001 
their presence during the Ramadan period in the Muslim areas is conspicuous, because they collect charity from each house of Muslim areas for the minor service they render during the period. Clearly speaking, they beat drums at nights during the Ramadan period to wake the people up to observe fasting. This is one of the prominent services that they have been rendering annually. However, this is by no means equivalent to caste divisions. It is also to be noted there are people like trustees of mosques, podiyaars(land lords) who are accorded a considerable respect due to the positions they hold in the society. However, this category of people has nothing to do with caste.

All these different categories of people in the Muslim society, particularly in the East emerge out of the cultural interaction they have had with the Hindus/ Tamil people, since both communities have been living side by side in the North East over a long period of time. Moors employed Tamil agricultural labor in their paddy lands, developed domestic reliance upon Tamil Washermen, and maintained commercial relationship with Tamil Barbers and Smith. Moreover, Moors intermarried Tamils/Hindus and thus converted them into Islam. Consequently, they shared the kinship patterns, matrilineal clan organization, matrilocal marriage system, and many other customary practices of the Hindu Tamils. This is exactly how the Muslims (Moorish population) in the Eastern province began to adopt the caste practices prevalent among the Hindu Tamils.

Moreover, these differences have been perpetuated by the elites in the society, purely because of their ulterior reasons/selfish reasons. One of the members from Osta family contends:

"Although we get along with many people in our society equally or normally, rich people in our society look at us differently and treat us in such a way. Therefore, we are not given a prominent position by them" (Interview 10).

The above statement suggests that those who are deemed as inferior in the society are looked down by the affluent or elites of the people. When I checked the Trustee board (Jummah Mosque administrators) of some Grant Mosques in Ampara district who are somewhat influential in the society, I hardly found a single member from the lower strata of the society, that is Osta or butchers, occupying the position as a trustee board member. This shows how differently these people have been treated, despite the religion (Islam) professes otherwise. Interestingly, many Trustee board members of Grand Mosques are selected based on the Kudi system, which is still dominant in the trustee board selection and marriage, when it comes to choosing partners (Jameel 2011).

Nevertheless, the discrimination endured by certain section of people on the basis of their birth and occupation in the Muslim society of Eastern province has drastically changed in the recent decades in view of the central role of Islamic movements that began to function in the late 1970s in Sri Lanka. The following section deals with those factors.

\section{Islamic Revivalist Movements and Caste Discrimination}

Islamic revivalism has a long history in Sri Lanka that can perhaps be traced back to colonial period where the Muslim educated elites like Siddi Lebbe and ILM Abdul Azeez were in the forefront promoting religious awareness for the social mobility and ethnic consolidation of the Muslims. As such, during the colonial period, they formed an Islamic movement called 'the Jamiyathul Islamiya' with the sole objective of promoting Islamic awareness among the Muslims, consolidating the Muslim identity and working towards the social and political development of the Muslims in Sri Lanka (Ameen 2000). The establishment of Madrasatul Bari, the first Arabic College founded in 1884 at Weligama by Seyed Mohamed Ibnu Ahamed Lebbe, popularly known as Mappillai Alim 
heralded a major transformation of religious identity of Muslims (Nuhman 2004). The postindependence era in Sri Lanka saw a vast number of Arabic colleges being established across the island and several Islamic revivalist movements emerged especially in the 1950s, which resulted in the Islamic revivalism among the Muslims in Sri Lanka. There are more than 200 Arabic colleges functioning in Sri Lanka at the moment, out of which almost 1000 students are annually passed out as religious scholars/Ulema (Nuhman 2004). Anecdotal evidence suggests that that there are more than 2000 mosques serving the religious needs of devotees in the island. Next section sheds light on the various revivalist movements that function across the island and their Islamic orientation towards the erosion of caste discrimination.

\section{Sufism}

Sri Lanka has a strong history of Sufism dating back several centuries, although some of its forms are more modern imports (Hussein 2007). Sufism is seen as a more mystical and ascetic form of Islam, although it subscribes to all the main theological tenets. A major element is the reverence of saints (Awliya, heads of sufi sects and sufi leaders), who are seen as intermediaries between the people and Allah. There are many shrines to these saints around the island, the most famous is that of Sheikh Usman Siddique at the Dawatagaha mosque in Cinnamon Gardens, Colombo. A significant number of shrines are also there across the island and people continue to worship them as well. Many Muslims visit these shrines with small offerings of money or food and supplications for a good harvest, a child or other material needs. As noted above, the first Qadiriya Tariqa was formed by Maappillai Aalim during the colonial period.

\section{Tabligh Jamaat}

The dominance of Sufism has been undermined by the increasing popularity of other Islamic sects over the past 50 years. Perhaps the most popular of these is Tabligh Jamaat, which has evolved as a mass movement in the last two decades but has been active since the 1953. (Nuhman 1997). It is a peaceful missionary movement whose followers devoted time and energy solely to make many nominal Muslims to become real Muslims. It has eschewed overt political activity and concentrated on encouraging Muslims to engage more actively in religious rituals such as five times prayers, propagation of Islam to their fellow Muslims and so on. They show no real interest in social work or the political problems facing the Muslims in Sri Lanka. Instead, they are mostly engaged in encouraging performance of religious rituals. They own code of ethics and attires for their members and their membership cuts across the society. Although it has had limited political impact, it seems certain that Tabligh Jamaat members have encouraged a more conservative view of Islam among many Sri Lankan Muslims.

\section{Jamaat-i Islamiyya}

Tabligh appeals across social classes and includes many urban professionals but anecdotal evidence suggests its rather simplistic approach to religious belief and antipathy towards political and social action is less popular among educated, middle-class Muslims, for whom the more intellectual approach of Jamaat-i-Islamiya (JI) has greater appeal. Although Jamaat i Ismai has been functioning in Sri Lanka from 1947, it was officially established here in 1954 with an idea of Islamicising the Muslim community in all its social aspects. (Nuhman 1997). It has attracted a considerable portion of educated middle class and youth and has a few branches and numerous study circles island wide. 
In Sri Lanka it has not openly advocated radical political ideas but has largely concentrated on religious orthodoxy and developing a new generation of sympathetic Muslim scholars. It is very influential in Islamic colleges and directly controls five major Arabic colleges (Nuhman 2004). Jamath i Islami, as a well-organized establishment, has its own publication and propaganda machinery. The researcher himself directly witnessed of a massive amount of social works that Jamath i Islami undertook during disasters in the country-both natural as well as man-made disasters.

\section{Tawheed Jamaat or Wahhabism}

Ultra-orthodox Islamic movement that falls into the broad category of Salafi movements is often referred to locally as "Thawheed Jamaat". It is derogatorily referred to as Wahhabi movement in the global context. This is a religious sect, which claims purity in belief but remained largely confined to the Arabian Penisula. Nevertheless, it was founded in 1947 by Abdul Hameed Al Bakry, popularly known as Dharvesh, when returned from Saudi Arabia studying on the Islamic Sharia. It has its own Arabic college in Paragahadeniya (Nuhman 1997). Thowheed Jamaat accepts only the Quran and Sunna and rejects all the customary folk religious practices from shrine worship to religious feasts as Shirk and bit'at(prohibited). Abdul Hameed and his disciples went to the extent of destroying some shrines in his village and as a result a case was filed against them in the District court in 1948 (Nuhman 1997). This incident becomes a clear manifestation of the extremist activity of Wahhabisim in Sri Lanka. Unlike Tabligh or Jamath i Islami, Wahhabis are not completely divorced from political life, but their involvement in electoral politics seems limited. Their preaching has also focused on purging Sri Lankan Islam of what are seen as deviations from the original Islam of the Arabian Peninsula, resulting from contact with Buddhism and Hinduism.

All these Islamic revivalist movements vehemently detest un-Islamic practices such as dowries and caste discrimination describing that it has intruded from Hindu culture to the Eastern Muslims and therefore, is viewed as contrary to Islamic tenets. In fact, this is the by-product of trends in global Islam that swept through the South Asia in 1970s with the Petro dollars pumped from Saudi Arabia, castigating all the rituals including caste discrimination as 'un-Islamic' practices.

Therefore, it is significant to note that the process of Islamiziation among Sri Lankan Muslims began following the emergence of these Islamic revivalist movements. Although there is a serious ideological difference between the Islamic revivalist movements, they have played an indispensable role in the development of religious awareness and erosion of caste existed in the form of discrimination among the Eastern Muslims of Sri Lanka in the past. The study reveals a hierarchy of caste the community is no more prevalent, given the Islamic revivalism that began in 1950s, but swept through South East Asia and South Asia including Sri Lanka in 1970s.

These Islamic movements began their religious propagation in the country that made a major difference in terms of the religious practices of Muslim society in Sri Lanka, particularly against caste discrimination. They advocated that there is no caste or unfair treatment of Muslims, purely because of their birth or jobs they do; they propagated for a change in the dress code of Muslims, reiterated on the halal dietary practices and established places of worships (mosques) across the country. A respondent notes:

"With the arrival of Islamic movements, all the traditional practices including treating people differently stopped. They labeled it as 'bidah'(innovation) and warns us of hellfire. So, we obediently obliged." (Interview 03 ). 
After 1973, Saudi Arabia with its petrodollars was able to propagate the ideology of Thowheeth(see Schwartz and Alawi 2013) among the Muslims society in Sri Lanka which openly challenged traditional practices like kattam and fathiha( reciting Quran in congregation at the funeral houses on $3^{\text {rd }}$ and $7^{\text {th }}$ day), Kudi system and some other unfair treatment of people like caste. This can be validated with the view expressed by a member of Usta families as follows:

"Works of Islamic movements, particularly Thowheed, is immense. They are the one who spearheaded their propaganda towards the eradication of discrimination against us. They opposed such discrimation and want all the people to treat equally as Islam emphasizes. If not for these Islamic movements, we would have suffered the same as we did before." (Interview 6).

The above reference is an illustration that represents the significant role of Islamic movements in the erosion of caste in the Muslim society. It appears that these Islamic movements spearheaded their propaganda machinery against discrimination or alienating people on the basis of their birth or profession. Instead, they spurred equality and brotherhood in Islam, which ended up treating members of Usta and butcher families equally in the Muslim society. However, the propagation of Islamic movements at times led to an internal conflict among the Sri Lankan Muslims, particularly between locally popular Sufi sheiks and the followers of Islamic reformist movements (Thowheed movement) characterized by ideas and resources from the world community of Muslims (Mcgilvray 2011). This could be supported with an assertion of the respondent:

"Propagation of Thowheed Jamath always led to rivalry between sects. Incidents in Beruwala and Kattankudy are cases in point. This, I believe, is one of the reasons that gave to rise to the Sinhala Buddhist extremism in the country" (Interview 08)

The above statement reveals that the rising wave of Islamic revivalism, due to the propagation of some Islamic movements, has not only done away with traditional practices like caste or discrimination of people in the Muslim society, but has become a source of tension between the Islamic movements/sects in Sri Lanka.

However, it should be applauded that the Islamic revivalism has significantly contributed to the decimation of discrimination or practices equivalent to caste among the Muslims in Sri Lanka. Majority of the respondents in the focus group discussions conducted both in Ampara and Batticaloa contended that religious propagation by Islamic movements in Friday's sermons and other special occasions targeting the ill-treatment and discrimination endured by people on the basis of their occupation and birth yielded positive outcome, which resulted in the erosion of caste discrimination in the Muslim community in Eastern Sri Lanka. This can clearly be seen in the responses of 15 interviewees conducted for this study, as shown below.

Chart 1 : Role of Islamic Dawa Movements in the Erosion of Caste Discrimination Among the Muslims in Eastern Sri Lanka 


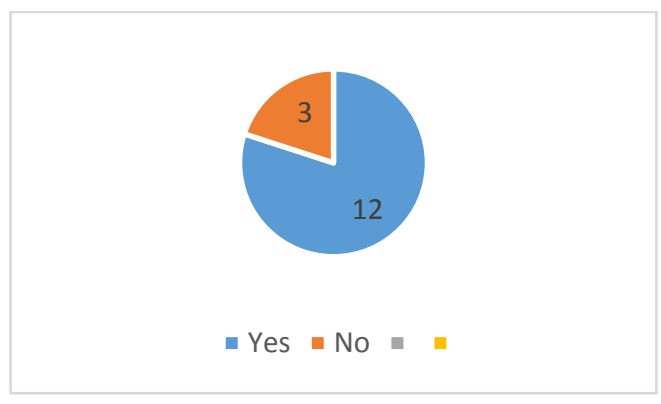

According to the table above, 12 respondents out of 15 interviewed for this study agree that Islamic Dawa movements (Islamic preachers' movements) played a significant role in the erosion of caste practices prevalent in the Muslim community in the Eastern Province. Their sustained campaign against caste based ill-treatment ensured that such a discrimination was no more in practice in the Muslim community. Moreover, the study finds that the advancement in education, globalization and urbanization also played a significant role in the erosion of caste discrimination among the Muslims in Eastern Sri Lanka. This can be manifested in the response given below:

"There is no caste among the Muslims in Sri Lanka as it is among Tamils. No one talks about caste discrimination in the present age of westernization or globalization. Even among Tamils, caste is on a dying stage now, particularly in the post war situation". (Interview 13).

As the people are grappled with a lot of challenges in the era of globalization, they are no more interested in conservative practices like caste in the community level. Moreover, the present day younger generation of Muslim community, particularly in the Eastern Sri Lanka is highly concerned about keeping abreast with the modern development of the world of technology and global industry. Moreover, their primary concern is to equip themselves academically qualified to compete in the global and local job market. Therefore, their concern is by no means to concentrate on caste discrimination in the society. The following figure is the manifestation of the responses of interviewees in the in-depth interviews in relation to how advancement of education, globalization and urbanization led to the erosion of caste practices in the Muslim community in Eastern Sri Lanka.

Table 1: Advancement of Education, Globalization and Urbanization Led to Erosion of Caste Discrimination

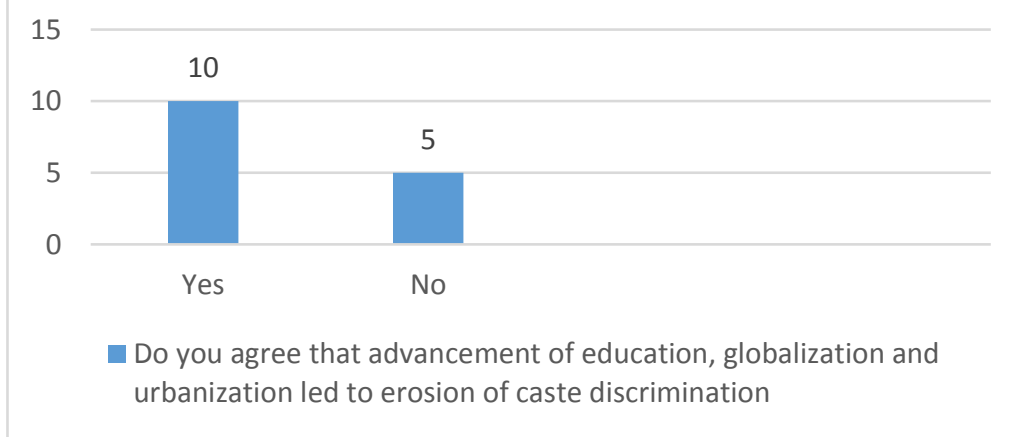

The above figure suggests that a majority of the respondents (10 out of 15 interviewees) endorse that the advancement of education, globalization and urbanization played a prominent role 
in the eradication of caste discrimination in the Muslim community in the Eastern Sri Lanka. Therefore, it is clear that not only Islamic revivalism, but the westernization and globalization also contributed to the erosion of caste discrimination among the Muslims in Sri Lanka.

To conclude, caste system has existed among the Muslims of Sri Lanka from the distant past. Moulana were placed in a privileged position, while the Osta and butchers were looked upon as inferior; further, their completely endogamous culture kept them separated. The inferior status in the society affected them not only in the social arena, but in the educational, economic and political arenas too. This unfair treatment was very similar to the caste discrimination practiced by the Hindu Tamils and could in fact be attributed to the cultural and linguistic influence of Tamils upon the Muslims in the Eastern Province where both communities have been living side by side for centuries. It is, however, important to note that those inferior groups such as Osta and butchers who experience discrimination at the hands of other Muslims are by no means equivalent to the 'untouchables' or Dalith people in India. The significant difference between the Hindus and Muslims in the case of caste groups is that the former attribute the status of these groups to their birth, while the latter does it to their cultural and social order. Thus, wiping out the caste divisions or groups among Hindus is almost impossible, while transforming the disadvantaged groups among Muslims equivalent to caste in Hindus is certainly possible. This premise, as shown in the findings, appears to have worked significantly among Muslims of Eastern Sri Lanka with the dynamic role of Islamic revivalist movements like Thabliq Jamaat, Thowheed, and Jamath e Islami that espoused egalitarianism and fraternity as basic tenets of Islam and played a significant role in the erosion of caste divisions among Muslim society.

Moreover, advancement of education, influence of globalization and urbanization have also contributed to the erosion of this practice among the Muslims in Sri Lanka, particularly the conservative Eastern Muslims. However, it can be seen that although the formation and spread of Islamic movements led to the fading away of discrimination and inegalitarianism in Muslim society, it has also aroused tensions within the various Islamic sects and ethnic groups in the country. Overall, it should be noted that unlike the Hindu Tamils or Sinhalese in Sri Lanka, caste has very little role to play in the social system of Muslim community in the Eastern Sri Lanka, primarily because of the dominant role of Islamic revivalist movements, which made a significant contribution in the erosion of caste discrimination in the society.

This study is a comprehensive and critical discussion on the role of Islamic revivalist movements in the erosion of caste divisions in among the Eastern Muslims of Sri Lanka and provides an insight to the readers, religious scholars whether caste, like in Hindu society, is still existent among the Muslims in Sri Lanka.

\section{References}

Ameen, M.I.M. 2000. Ilakai Muslimkalin Varlaarum Kalaasaaramum (1870-1915). Hemmaatugama: Al-Hasanath Publication.

Dube, S.C. 2010. Indian Society. Delhi: National Book Trust.

Fuller, C.J. 1997. Caste Today. New Delhi: Oxford University Press.

Farooq, U. 2012. Study Lecture Notes (online). http://www.studylecturenotes.com/socialsciences/sociology/377-caste-system-meaning-definition-a-characteristics-of-caste-system [20th October 2016].

Guha, Sumit. 2013. Beyond Caste: Identity and Power in South Asia, Past and Present Leiden: E.J. Brill. Hussein, Asiff. 2007. Sarandib: An Ethnological Study of the Muslims of Sri Lanka. Dehiwela: A.J.Print Pvt Ltd. 
Jaffrelot, Christophe. 2006. 'Untouchables, Scheduled Castes and Dalits in the Indian Republic'. In Christophe Jaffrelot. India Since 1950: Society, Politics, Economy and Culture. New Delhi: Yatra Books.

Jameel, S.H.M. 2011. History of Sainthamaruthu. Sainthamaruthu: Grand Mosque.

Mcgilvray, D.B. 2011. Sri Lanka Muslims: Between Ethno Nationalism and Global Ummah. Nations and Nationalism. 17(1): 45-64.

Mcgilvray, D.B. 1982. Caste Ideology and Interaction. Cambridge: Cambridge University Press.

Nuhuman, M.A. 2004. Understanding Sri Lankan Muslim Identity. Colombo: International Center for Ethnic studies.

Nuhuman, M.A. 1997. Ethnic Identity, Religious Fundamentalism and Muslim Women in Sri Lanka. In MWRAF. Alternative Perspectives: A collection of Essays on Contemporary Muslim Society. Colombo: Muslim Women's Research and Action Forums.

Provincial Planning Secretariat. 2015. Map of Sri Lanka. Available From: http://www.np.gov.lk/index.php?option=com_content\&view=article\&id=2665:provincialplanning-secretariat-2\&Itemid=101 Retrieved: 20th March 2018.

Rao, Jasmine. 2010. The Caste System: Effects on Poverty in India, Nepal and Sri Lanka. Global Majority E-Journal. 1(2): 97-106.

Tudor Silva, Sivapragasam, P.P and Thanges, Paramsothy (Eds). 2009. Casteless or Casteblidn: Dynamics of Concealed Caste Discrimination, Social Exclusion and Protest in Sri Lanka. Chennai: Kumaran Book House.

Schwartz, Stephen and Alawi, Irfan. 2013. Wahhabi Invasion of Sri Lanka, Colombo Telegraph. Colombo Telegraph. 27th March 2013. https://www.colombotelegraph.com/index.php/thewahhabi-invasion-of-sri-lanka/ [20th March 2018].

Thiruchandran, S. 1997. Ideology, Caste, Class and Gender. New Delhi: Vikas Publishing House PVT ltd.

Thorat, Sukhado and Umakant. 2004. Caste, Race and Discrimination. Jaipur: Rawat.

\section{List of Interviewees}

\section{Name}

1. Interview 01

2. Interview 02

3. Interview 03

4. Interview 04

5. Interview 05

6. Interview 06

7. Interview 07

8. Interview 08

9. Interview 09

10. Interview 10

11. Interview 11

12. Interview 12

13. Interview 13

14. Interview 14

15. Interview 15
Village

Kalmunai

Akkaraipattu

Muthur

Kattankudy

Mawadippalli

Sainthamaruthu

Kinniya

Maruthamunai

Kalmunai

Eravur

Akkaraipattu

Kalmunai

Kinniya

Sainthamaruthu

Kattankudy
Profession

Gov.servant

Private employee

Religious scholar

Govt.servant

Business sector

Unemployed

Business sector

Foreign employee

Social activist

Laborer/barber

Laborer

Laborer/Butcher

Social worker

Unemployed

Business sector 